ARCHIWA - Kancelarie - ZBIORY

NR 6(8)/2015

MARCIN FRĄŚ

Uniwersytet Mikotaja Kopernika

\title{
Problematyka zaWartości I Wartości PROFili UŻYTKOWNIKÓW NA PORTALACH HOBBYSTYCZNYCH
}

http://dx.doi.org/10.12775/AKZ.2015.009

Słowa kluczowe

filmweb.pl; last.fm; lubimyczytac.pl; portale hobbystyczne; portale społecznościowe; archiwizacja Internetu; wartościowanie zasobów Internetu; zasoby cyfrowe;

Keywords

filmweb.pl; last.fm; lubimyczytac.pl; hobby web portals; social networking services; archiving the Internet; Internet content evaluation; digital holdings

Streszczenie

W artykule zostały przedstawione rozważania dotyczące wartości i zawartości profili użytkowników na portalach hobbystycznych. Badana problematyka jest częścią większego zagadnienia. Chodzi o zachowanie osobistych zbiorów cyfrowych. Szczegółowej analizie zawartości, analizie źródłoznawczej i ego-dokumentalnej została poddana witryna filmweb.pl.

(Clem artykułu jest zwrócenie uwagi na to, iż wraz z rozwojem technologii i Internetu tworzone są nowoczesne źródła do badań mentalności. Oma- 
wiany problem jest także częścią większego zagadnienia - zachowania osobistych zbiorów cyfrowych. W tekście omówiona zostanie zawartość trzech portali hobbystycznych, ich budowa i możliwości, jakie dają użytkownikom. Postawiono też pytanie, na które starano się uzyskać odpowiedź: czy warto archiwizować tego typu zasoby Internetu? Przedmiotem badań ze względu na własne zainteresowania autora są portale hobbystyczne, takie jak: Filmweb ${ }^{1}$, Lubimyczytać.pl ${ }^{2}$, Last.fm ${ }^{3}$, choć szczegółowej analizie poddano jedynie zawartość portalu Filmweb.

Punktem wyjścia do rozważań jest klasyczne pojęcie egodokumentu wprowadzonego do użycia w środowisku naukowym przez holenderskiego historyka Jacoba Pressera ${ }^{4}$ w 1958 roku. W dalszej części pragnę przedstawić wyniki moich badań.

Jacob Presser egodokumenty rozumiał jako: „źródła historyczne o charakterze osobistym”, zazwyczaj pisane w pierwszej osobie liczby pojedynczej. Obecnie egodokumenty funkcjonują w nurcie antropologii historycznej z naciskiem na historię mentalności i mikrohistorię. Do grupy egodokumentów zaliczyć można przede wszystkim wszelkiego rodzaju teksty autobiograficzne takie jak pamiętniki i dzienniki, ale także testamenty czy protokoły przesłuchań świadków ${ }^{6}$.

W dzisiejszych czasach dzięki nowoczesnym technologiom mamy większe niż dotychczas możliwości wyrażania i pokazywania siebie, a także w zakresie rejestracji rzeczywistości. Możliwe jest to między innymi dzięki rozmaitym narzędziom internetowym, również portalom hobbystycznym, których zawartość i wartość chciałbym omówić. Zdaję sobie sprawę z istnienia innego typu narzędzi, często wprost pozwalających człowiekowi wyrażać siebie,

1 Filmweb [dostęp 01 grudnia 2015]. Dostępny w WorldWide Web: http://www. filmweb.pl.

2 Lubimyczytać.pl [dostęp 01 grudnia 2015]. Dostępny w WorldWide Web: http:// lubimyczytac.pl.

3 Last.fm [dostęp 01 grudnia 2015]. Dostępny w WorldWide Web: http://www.lastfm.pl.

4 S. Roszak, Egodokumenty epoki nowożytnej w perspektywie europejskiej, [w:] Z dziejów staropolskiego pamiętnikarstwa: przekroje i zbliżenia, red. P. Borek, Kraków 2012, s. 15.

5 W. Chorążyczewski, A. Rosa, Metodologiniai lietuviškuju egodokumentu paieškos aspektai lenkišku požiūriu (pol. Metodologiczne aspekty poszukiwań egodokumentów litewskich z perspektywy polskiej), [w:] Egodokumentai ir privati Lietuvoserdve XVI-XX amžiuje, red. A. Paceviciuss, Vilniaus Universiteto leidykla 2013, s. 7.

6 S. Roszak, Egodokumenty, s. 15. 
zwłaszcza blogów czy osobistych stron internetowych i innych podobnych miejsc w Internecie. Ze względu na marginalizowanie zjawiska, a także osobiste zainteresowania analizie poddałem portale hobbystyczne.

Pierwszy z analizowanych portali to „Lubimyczytać.pl”.

Jest to witryna założona w 2009 roku. Strona ta pełni funkcję internetowej bazy danych oraz portalu społecznościowego. Jak sama nazwa wskazuje, obszarem jej zainteresowania jest szeroko rozumiana literatura i ludzie z branży (głównie pisarze). Baza książek uzupełniana jest na bieżąco, poza tym w serwisie znaleźć można świeże informacje z rynku książek, w tym: informacje o bestsellerach, seriach wydawniczych (wspólna nazwa, podobny układ i szata graficzna, ale autor i tytuł mogą być inne), cyklach (kilka książek tego samego autora związanych ze sobą treścią), wydawnictwach, wywiadach z pisarzami oraz zaproszeniach na książkowe imprezy.

Większość opcji na tym portalu dostępna jest dla użytkowników po uprzednim zalogowaniu się. Użytkownik w wyniku bezpłatnej rejestracji otrzymuje swój własny profil. Logowanie w serwisie możliwe jest także przez skojarzenie z kontem użytkownika na facebooku. W skład narzędzi oddanych do dyspozycji użytkowników wchodzi: darmowy kurs kreatywnego pisania, możliwość przeczytania (w formie ebooka) lub odsłuchania (w formie audiobooka) wybranych książek, poczta wewnętrzna, dodawanie/usuwanie z listy znajomych, biblioteczka, dodawanie komentarzy (opinii), samodzielne tworzenie opisów dla informacji o nowych książkach czy autorach, założenie i prowadzenie bloga. Konto użytkownika jest możliwe do usunięcia.

Drugi z analizowanych portali to „Last.fm”.

Last.fm zostało utworzone w 2002 roku przez pochodzących z Austrii i Niemiec Feliksa Millera, Martina Stiksela, Michaela Breidenbrueckera oraz Thomasa Willomitzera, Podobnie jak opisany wcześniej portal „Lubimyczytać.pl" funkcjonuje jako połączenie bazy internetowej i portalu społecznościowego. W polu zainteresowania znajduje się szeroko rozumiana muzyka.

Sama strona dostarcza informacji o tym, co jest obecnie na topie, z podziałem na poszczególne kategorie muzyczne. Oferuje możliwość korzystania z darmowego radia internetowego wraz z dostępem do wielu stacji. Zbiera także informacje o aktualnych wydarzeniach z branży lub o tych, które dopiero nastąpią w przyszłości. Stronę można przeglądać jako niezalogowany użytkownik. Jednak dostęp do pełnej wersji i wszystkich usług uzyskać można tylko dzięki rejestracji (możliwe jest także skojarzenie z kontem użytkow- 
nika na facebooku, Yahoo czy Google mail). Konto użytkownika jest możliwe do usunięcia.

Trzeci z analizowanych portali to „Filmweb”.

Jest to portal internetowy łączący w sobie funkcje portalu społecznościowego z internetową bazą danych, którego główną tematyką są filmy oraz ludzie ze świata kina. Poza tym Filmweb zbiera również informacje o grach przewidzianych na różnego typu platformy (konsola Xbox, Playstation, PSP oraz PC). Witryna powstała 18 marca 1998 roku i z powodzeniem funkcjonuje do dziś. Zawiera codzienne informacje ze świata filmu, recenzje, zapowiedzi premier kinowych i DVD, zwiastuny, tapety, galerie zdjęć, fora dyskusyjne, boxoffice, czyli liczbę widzów lub dochód ze sprzedaży biletów w przełożeniu na dany film, repertuar kin w całej Polsce, program TV, rankingi, konkursy, informacje o dystrybutorach i festiwalach.

Dostęp do wszystkich narzędzi na stronie użytkownik otrzymuje dopiero po uprzednim zarejestrowaniu się. Podobnie jak w przypadku dwóch pozostałych serwisów możliwe jest logowanie za pomocą konta użytkownika na facebooku. W skład narzędzi (oprócz tych) oddanych do dyspozycji użytkowników wchodzą: blog, recenzja, usługa dodawania materiałów dotyczących filmów i ludzi z branży. Konto użytkownika nie jest możliwe do usunięcia.

Tabela. Narzędzia dla użytkowników na portalach Lubimyczytać.pl, Filmweb.pl, Last.fm

\begin{tabular}{|l|c|c|c|c|c|c|c|}
\hline \hline \multicolumn{1}{|c|}{ Portal } & $\begin{array}{c}\text { Poczta } \\
\text { wewnętrzna }\end{array}$ & $\begin{array}{c}\text { Lista } \\
\text { znajomych }\end{array}$ & $\begin{array}{c}\text { Biblio- } \\
\text { teczka }\end{array}$ & Blog & Recenzja & Komentarze & $\begin{array}{c}\text { System } \\
\text { ocen }\end{array}$ \\
\hline \hline $\begin{array}{l}\text { Lubimyczy- } \\
\text { tać.pl }\end{array}$ & + & + & + & + & - & + & + \\
\hline Filmweb.pl & + & + & + & + & + & + & + \\
\hline Last.fm & + & + & + & - & - & + & - \\
\hline \hline
\end{tabular}

Źródło: opracowanie własne.

Powyższa tabela przedstawia wachlarz podstawowych usług, z których mogą korzystać użytkownicy na omawianych portalach. Jak widać, usługi te (narzędzia) są we wszystkich trzech portalach zbieżne co do: poczty wewnętrznej, listy znajomych, biblioteczki oraz dodawania komentarzy. Natomiast nie wszystkie portale dają możliwość dodawania ocen i prowadzenia bloga, a tylko jeden umożliwia wystawianie recenzji. 


\section{Poczta Wewnętrzna}

Dzięki niej użytkownicy mogą porozumiewać się ze sobą. Komunikacja ta opiera się głównie na przesyłaniu i odpowiadaniu na otrzymane wiadomości prywatne. Podzielona jest na wiadomości przeczytane i nieprzeczytane. Możliwe jest zarządzanie nimi.

\section{LISTA ZNAJOMYCH}

Strony te łączą ze sobą funkcje portalu społecznościowego z bazą danych. Zatem jednym z najważniejszych czynników warunkujących funkcjonowanie takiego portalu są tworzący go ludzie. Użytkownik może stale powiększać swoją listę. Możliwe jest to za sprawą manualnego przeszukiwania serwisu. Dzieje się tak za pomocą specjalnego pola combo, które umożliwia przeszukiwanie portalu wg nazwęy poszukiwanego użytkownika lub rzeczywistych danych personalnych. W przypadku profilu na last.fm znajomych można szukać, łącząc swój profil z facebookiem oraz przeglądarką Yahoo czy Google mail. Oczywiście istnieje także możliwość blokowania lub usuwania tych osób z listy.

Na portalu last.fm oprócz znajomych użytkownik ma możliwość korelacji z tak zwanymi „sąsiadami”, czyli osobami o podobnym guście muzycznym.

Normą wszystkich tych trzech serwisów jest fakt, iż umożliwiają zrzeszanie się w grupy. Można się do nich zapisać lub stworzyć własną grupę, a także sprawdzać, które grupy są popularne lub nowe.

Możliwe jest także „podglądanie” innych użytkowników. Jednakże wiąże się to z tym, że my również możemy być obserwowani. Dzięki „podglądaniu” dowiedzieć się możemy o ostatniej aktywności w serwisie oraz o tym, co aktualnie czytają/słuchają/oglądają nasi znajomi.

\section{BibliotekA}

W każdej z wymienionych stron opcja ta umożliwia publikację informacji (w formie notatnika) dotyczących przeczytanych książek, obejrzanych filmów czy odsłuchanych utworów oraz ich autorów wraz z oceną w skali od 1 do 10 . 
W przypadku portalu Lubimyczytać.pl zarejestrowani użytkownicy mogą poinformować, kiedy dokładnie skończyli czytać daną książkę, podając datę w systemie (dzień-miesiąc-rok). Dodatkowo użytkownik ma możliwość poinformowania, czy jest w posiadaniu danej książki, dodając ją na odpowiednią „półkę”. W zakładce tej można także umieszczać informacje o ulubionych cytatach z książek.

W serwisie Last.fm bibliotekę muzyczną można tworzyć na dwa sposoby - manualnie dodając ulubionych wykonawców do listy, wybierając ich spośród listy rekomendowanych, albo rejestrując odsłuchane, posiadane utwory. Odbywa się to przy użyciu specjalnej aplikacji - „Audioscrobbler”, którą najpierw trzeba zainstalować na komputerze. Dzięki niej możliwe jest przesyłanie informacji o przesłuchanych plikach muzycznych i zapisywanie na profilu użytkownika, co tworzy spersonalizowaną tabelę ulubionych wykonawców/utworów i muzyczne rekomendacje. Tabela ta podaje informacje o ulubionych zespołach wraz z liczbą przesłuchanych utworów danej grupy. Pokazuje całkowitą liczbę odtwarzanych utworów w perspektywie 12, 6 lub 3 miesięcy, miesiąca oraz ostatnich $7 \mathrm{dni}$. Analogiczne dzieje się w odniesieniu do pojedynczych piosenek. Informacja o czasie, kiedy został odsłuchany dany utwór muzyczny, jest przekierowywana automatycznie i użytkownik nie ma na to żadnego wpływu.

$\mathrm{Na}$ Filmweb profil użytkownika umożliwia publikację informacji dotyczących obejrzanych filmów lub tych, które użytkownik ma zamiar obejrzeć. To samo jest możliwe w odniesieniu do ludzi ze świata kina oraz gier na różnego typu platformy. Ponadto użytkownik ma możliwość oceny pracy reżysera, scenariusza, montażu, scenografii, zdjęć, dźwięku i muzyki do filmu oraz produkcji. Data generowana jest automatycznie, w momencie kiedy dodawana jest ocena.

\section{Komentarze}

Wszystkie przebadane portale dają użytkownikom możliwość ekspresyjnego wyrażania siebie przez dodawanie wpisów (często dość krótkich, dwu-, a nawet jednowyrazowych) o charakterze opiniodawczym. Tego rodzaju wpisy przesiąknięte są emocjami, użytkownicy mogą nimi wpływać także na opinie innych użytkowników portalu. 
Na portalu last.fm komentarze można zostawiać w miejscach określonych jako „shoutbox”, umożliwiających odwiedzającym bardzo szybką wymianę zdań bez potrzeby wysyłania trwałych wiadomości.

\section{BLOG}

Jest to narzędzie, którego nie ma na stronie Last.fm, mają je za to Filmweb. pl i Lubimyczytać.pl. Jak sama nazwa wskazuje, jest to usługa, dzięki której można tworzyć prywatny dziennik sieciowy. Wpisy zamieszczone na blogu ułożone są chronologicznie. Ciekawostką może być fakt, iż na portalu filmweb.pl przygotowano narzędzie, dzięki któremu treść wpisów może zostać zarchiwizowana na stronie. Możliwe jest także tzw. tagowanie wpisów, czyli oznaczanie znakami lub słowami kluczowymi. Służy to kategoryzacji i klasyfikacji zawartości, a w dalszej perspektywie łatwiejszemu poruszaniu się po już wniesionych wpisach.

\section{RECENZJA}

Ta usługa dostępna jest jedynie na portalu Filmweb.pl. Jest to opcja, dzięki której użytkownik może opublikować na stronie danego filmu lub osoby z branży swoją własną analizę połączoną z oceną.

\section{WNIOSKI}

Omówione portale są swoistym formularzami pozwalającymi użytkownikom na pewną aktywność - użytkownik wpisuje swoje dane (może to być sam login, pseudonim, ale też pełne imię i nazwisko), daje gwiazdki, może też przystąpić do grupy, napisać recenzję, opis, wiadomość, komentarz, stworzyć swoją listę ulubionych utworów/wykonawców itp. Portal daje możliwość, a nawet skłania do określonej aktywności swoich użytkowników. Biorąc pod uwagę powyższe, wypada zadać pytanie: ile zatem człowieka, jego wkładu, osobowości znajduje się w tych trzech portalach? Odpowiedź oczywiście jest zależna od tego, jak mocno dany użytkownik angażuje się w budowanie swojego profilu na portalu. 
Szukając odpowiedzi na postawione wyżej pytanie: „czy warto archiwizować tego typu zasobu Internetu”, poddałem analizie źródłoznawczej i egodokumentalnej ${ }^{7}$ zawartość jednego z omówionych portali - portalu Filmweb. Uważam, że analiza przeprowadzona dla pozostałych dwóch portali może dostarczyć podobnych informacji, różniących się jedynie przedmiotem poznania.

Wartość zawartości profilu użytkownika zlokalizowanego na portalu hobbystycznym Filmweb zależy od dwóch czynników. Po pierwsze od tego, jak bardzo ktoś udziela się na tego typu portalach (ile jest tam informacji). Po drugie zaś od sposobu wykorzystania tego rodzaju źródła. Odnosi się to do sedna definicji egodokumentu. Profile są formą samoświadectwa. W tym przypadku nie występuje żadna osoba pośrednicząca. Dzięki tym świadectwom w ujęciu mikrohistorycznym możemy badać osobowość pojedynczego człowieka, oczywiście jeżeli możliwa jest jego identyfikacja, lub mentalność całej zbiorowości. Źródło to jest cenne choćby z tego powodu, że wymyka się z ram konwencji. Jest całkowicie świeże. Może funkcjonować zarówno samodzielnie, jak i wspomagać inne źródło w badaniach historycznych, antropologicznych, etnologicznych czy socjologicznych.

Autorami są przeważnie zwykli ludzie, pojedyncze osoby, pasjonaci kina, często przybierający pseudonimy, za którymi się kryją. Nie zawsze są to jednak osoby anonimowe. Tylko jeżeli sami tego chcą, można poznać ich z imienia i nazwiska. Porozumiewają się zazwyczaj w języku swojej narodowości. Niekiedy mogą komunikować się za pośrednictwem specyficznych zwrotów lub symboli, zazwyczaj w zależności od tego, do jakiej grupy społecznej należą lub jaki mają status społeczny.

Adresatem źródła są inni użytkownicy posiadający konto na Filmweb oraz ci, którzy tylko przeglądają portal. Ich zetknięcie następuje w momencie, kiedy jedna ze stron opiniuje dzieło filmowe (komentuje je), a druga szuka na ten temat informacji.

Zakładając swój profil, autorzy mają pewną intencję, logując się w serwisie. Intencją tą jest zapewne wymiana myśli i spostrzeżeń dotyczących kinematografii, szukanie informacji na ten temat. Każdy użytkownik ponadto

7 W. Chorążyczewski, A. Rosa, Egodokumenty - egodokumentalność - analiza egodokumentalna - spuścizna egodokumentalna, [w:] Egodokumenty. Tradycje historiograficzne - perspektywy badawcze, red. W. Chorążyczewski, A. Pacevicius, S. Roszak, Toruń 2015 [w druku]. 
mógł być zainspirowany do jego stworzenia, czy to przez rówieśnika, czy to przez kogoś z rodziny, znajomych, otoczenia.

Źródło to daje możliwość wejrzenia w mentalność, świat wartości oraz emocjonalność autora. Aktywność na portalach społecznościowych sama w sobie jest jakąś formą przejawu osobowości autora. Zbadanie tego zjawiska uzależnione jest niejako od tego, na ile dany człowiek angażuje się w tworzenie tego źródła - swojego profilu. Chodzi o to, czy dana osoba robi wszystko, aby zostać zauważoną: pisze komentarze, tworzy blogi i regularnie dodaje na nim wpisy, bardzo często dodaje do swojego profilu informacje o tym, jaki film obejrzała i jak go oceniła etc. Z drugiej strony autor może być typem osoby, która nie pisze komentarzy, nie tworzy blogów, ogranicza się co najwyżej do dodawania informacji o obejrzanych filmach etc., innymi słowy stara się nie zwracać na siebie uwagi.

Analizując z kolei sposób, w jaki autor konstruuje komentarze, przede wszystkim można zaobserwować: czy zna podstawowe zasady ortografii i interpunkcji, czy w swoich wypowiedziach wykazuje się erudycją, czy odnosi się z szacunkiem do innych lub czy używa inwektyw w zależności od sytuacji. Użytkownik piszący długi tekst ponadto może ukazać opanowanie sztuki przekonywającego wysławiania się, a nawet ujawnić się ze swoim gadulstwem.

Jeżeli chodzi o publikowane treści, to zaobserwować można także pewnego rodzaju nacisk społeczny. Treść tych informacji zależy od tego, kim jest dana osoba (mężczyzną czy kobietą), czym zajmuje się w życiu (zawód), a co za tym idzie, jakie ma poglądy i jaki chce mieć wizerunek w sieci. Autor przy tym może wykazać się konformizmem lub nonkonformizmem.

Zaistnieć może sytuacja, w której autor dodaje wpisy odnoszące się do treści filmów będących obecnie na topie. Może rzeczywiście je lubić, bo takie są akurat jego zainteresowania, ale zdarzyć się może, że polubi coś i oceni wysoko, bo tak wypada, takie są oczekiwania jego grupy. Zrobi to, aby wpasować się do otoczenia i po prostu nie być z niego wykluczonym. Przykładem takich zachowań może być wzrost zainteresowania filmem pt. „Pięćdziesiąt twarzy Greya”, który niewątpliwie osiągnął sukces komercyjny, mimo że treści w nim zawarte wzbudzają wiele kontrowersji, a oceny były niezbyt wysokie.

Źródło pokazuje np. także mentalność mężczyzn, którzy raczej nie dodają do listy oglądanych filmów dzieł z kategorii „komedia romantyczna”, „romans” czy „melodramat”, choć oglądają też i takie kino. Zazwyczaj nie przy- 
znają się do tego na swoich profilach. Analogicznie dzieje się w przypadku, gdy dorosła osoba ogląda bajki.

Oglądanie wielu filmów z różnych kategorii może być świadectwem ukazującym szerokie zainteresowania autora. $Z$ drugiej strony może zdarzyć się sytuacja odwrotna, autor może być skupiony tylko na wybranych kategoriach filmów. Poza tym witryna ta, dając użytkownikom możliwość dodawania recenzji, niejako tworzy środowisko krytyków amatorów.

\section{Podsumowanie}

Reasumując, należy zastanowić się nad zachowaniem tego rodzaju źródeł z uwagi na fakt, iż pokazują otaczającą nas rzeczywistość z zupełnie innej perspektywy, subiektywnej. Postulat zachowania tego typu źródeł wyrósł na gruncie postmodernistycznego paradygmatu funkcjonującego w humanistyce, w myśl którego tradycyjne źródła historyczne (zarówno w postaci analogowej, jak i elektronicznej) są niewystarczające do badań mikrohistorycznych. Natomiast źródła subiektywne, samoświadectwa, czyli tradycyjne pamiętniki, korespondencja, ale też i elektroniczne blogi, profile na portalach społecznościowych i hobbystycznych, stały się obiektem szczególnego zainteresowania wśród badaczy. Wykorzystywanie ich do badań zbiegło się w czasie z rozwojem postmodernistycznego paradygmatu, a nie z przejściem dokumentacji papierowej na elektroniczną. Rozwój technologii informatycznych doprowadził jednakże do niespotykanej w dziejach możliwości wyrażania się człowieka - tworzenia egodokumentów. Wiele z nich funkcjonuje wyłącznie w cyberprzestrzeni.

$\mathrm{Z}$ tego właśnie powodu obiekty takie jak analizowane przeze mnie portale i zamieszczone na nich profile użytkowników warte są długoterminowego zachowania. Tego typu teksty powstające na portalach hobbystycznych są unikatowe. Portale społecznościowe to nie tylko zestaw rozmaitych podstron, na których publikowane są wybrane treści, ale przede wszystkim system relacji między użytkownikami. Należy zastanowić się, czy i w jaki sposób można te relacje archiwizować.

W tym miejscu rodzą się kolejne pytania: czy twórcy tego rodzaju portali powinni mieć możliwość decydowania o tym, czy chcą to zachować, czy nie? I jeśli nie oni mają o tym decydować, to kto? Przecież pomimo unikatowości treści użytkownikom korzystającym z serwisu przysługuje fundamentalne 
prawo do zapominania. I jeżeli mają taką potrzebę, to ich profile nie powinny zostać zachowane. Ludzi często obdziera się z tego prawa, a przynajmniej regulamin wszystkich trzech serwisów opisanych wyżej milczy w tej kwestii. Następną ważną kwestią jest to, kto prawnie jest właścicielem pojedynczego profilu. Czy będzie nim biznesmen (właściciel spółki Filmweb.pl sp. z o.o.), czy każdy użytkownik, który kiedykolwiek założył profil w serwisie?

Bibliografia

Chorążyczewski W., Rosa A., Egodokumenty-egodokumentalność-analiza egodokumentalna-spuścizna egodokumentalna, [w:] Egodokumenty, tradycje historiograficzne i perspektywy badawcze, red. W. Chorążyczewski, A. Pacevicius, S. Roszak, Toruń 2015, s. 11-21.

Chorążyczewski W., Rosa A., Metodologiniai lietuviškuju egodokumentu paieškos aspektai lenkišku požiūriu (pol. Metodologiczne aspekty poszukiwań egodokumentów litewskich z perspektywy polskiej), [w:] Egodokumentai ir privati Lietuvoserdve XVI-XX amžiuje, red. Arvydas Paceviciuss, Vilniaus Universiteto leidykla, 2013, s. 7.

Roszak, S., Egodokumenty epoki nowożytnej w perspektywie europejskiej, [w:] Z dziejów staropolskiego pamiętnikarstwa: przekroje i zbliżenia, pod. red. P. Borek, Kraków 2012, s. 15.

\section{Summary}

The problem of content and value of users' profiles on hobby web portals

The article introduces deliberations concerning value and content of users' profiles on hobby web portals. The studied issue is a part of a wider problem, touching preservation of personal digital materials. The portal filmweb.pl was specifically studied on the basis of content analysis, source analysis and ego-document analysis. 